\title{
DEREGULATION CONTROL BY MERGERS AND ACQUISITIONS: A GAME THEORETIC ANALYSIS OF THE CHINESE AIRLINE INDUSTRY
}

\author{
Joshua IGNATIUS ${ }^{1,2^{*}}$, Tian Siang TAN ${ }^{2}$, \\ Lalitha DHAMOTHARAN ${ }^{1,3}$, Mark GOH $^{4,5}$ \\ ${ }^{1}$ WMG, University of Warwick, Coventry, UK \\ ${ }^{2}$ School of Mathematical Sciences, Universiti Sains Malaysia, Penang, Malaysia \\ ${ }^{3}$ School of Management, Universiti Sains Malaysia, Penang, Malaysia \\ ${ }^{4}$ NUS Business School, National University of Singapore, Singapore \\ ${ }^{5}$ The Logistics Institute-Asia Pacific, National University of Singapore, Singapore
}

Received 06 October 2015; accepted 25 November 2016

\begin{abstract}
The major challenges of deregulation are lax market entry, sudden surge in new market entrants, and the intense price wars that ensue, thus causing major losses for any industry. This paper investigates whether deregulation can be structured through a controlled Mergers and Acquisitions (M\&As) process by means of government intervention, and how this promotes the performance of the players in the industry. We study this in the context of the Chinese aviation industry as an ideal microcosm of our problem statement. This is because China's civil aviation industry has witnessed many of the above challenges since its deregulation and economic reforms in 1979, which saw the beginning of a transformation from a fully state-owned machinery to a rent-seeking private sector. The post controlled deregulation process through M\&As led to three dominant carriers: Air China Limited (AC), China Southern Airlines (CS), and China Eastern Airlines (CE). Using a 3-player non-cooperative perfect information Cournot oligopoly game model, the strategic efficacy of the government intervention to consolidate the industry based on operating expenses, air passenger revenue, and profit data are investigated respectively. All three airlines are better off after the exercise, with the industry facing a more sustainable growth by the intervention.
\end{abstract}

Keywords: game theory, airlines, aviation, industry consolidation, mergers and acquisitions.

JEL Classification: L51, C71, C72.

\section{Introduction}

The start of China's aviation industry was when important gateway cities were connected via air travel in 1930s. A joint venture of China National Aviation Corporation (CNAC) was formed after the U.S. Curtiss-Wright's negotiations with the Guomindang party (Dougan

${ }^{\star}$ Corresponding author. E-mail: joshua_ignatius@hotmail.com

This is an Open Access article distributed under the terms of the Creative Commons Attribution License (http://creativecommons. org/licenses/by/4.0/), which permits unrestricted use, distribution, and reproduction in any medium, provided the original author and source are credited. 
2002). Under the People's Republic of China administration, a Civil Aviation Bureau (CAB) was set up and made accountable to the Central Military Commission (CMC) after the end of the political internal conflicts between Guomindang and the Communist Party in 1949. The state (also refers to the Chinese Communist Party) monopolized the aviation industry in the earlier stages. With the exception of Southwest Airlines, which was run independently, the state controlled the other airlines. This is due to the industry's importance in China's military (the national defence and security), politics, and economic areas. Later, CMC formed a joint management with the State Council in 1985, and the CAB is now known as The Civil Aviation Administration of China (CAAC). CAAC served as both the regulatory and the owner of the aviation authority.

Prior to 1978, China's aviation industry was operated and controlled by the state, under a tightly regulated system. On 15 March 1980, the CAAC became independent of the military, and has since implemented regulatory reforms as part of its decentralization process. As a result, more decision-making power was given to regional and provincial civil aviation bureaus. The CAAC was divided into six regional and provincial aviation bureaus (Lei, O'Connell 2011). Table 1 shows the six airlines formed by the regional bureaus respectively under further reformation in 1987. From the mid-1980s to early 1990s, the industry reformation ended the CAAC's monopoly and created a competitive market place for the aviation industry. As a result, it lessened the barriers to entry for the more provincial, non-CAAC airlines.

Table 1. Airline companies formed from the six bureaus in the late 1980s

\begin{tabular}{|l|l|l|}
\hline \multicolumn{1}{|c|}{ Bureau } & \multicolumn{1}{c|}{ Location } & \multicolumn{1}{c|}{ Airlines Formed } \\
\hline Northern Bureau & Beijing & Air China Limited \\
\hline Southern Bureau & Guangzhou & China Southern Airlines \\
\hline Eastern Bureau & Shanghai & China Eastern Airlines \\
\hline Southwest Bureau & Chengdu & China Southwest Airlines \\
\hline Northern Bureau & Shenyang & China Northern Airlines \\
\hline Northwest Bureau & Xian & China Northwest Airlines \\
\hline
\end{tabular}

Previous research had analysed the Chinese aviation industry based on its major economic and political reforms between the period 1970 and 2002 (Dougan 2002). The evidence shows that after four stages of reformation (marketization, destatization, decentralization, and globalization), the aviation industry had turned from a strictly regulated industry into a partially deregulated industry. The state's authority over the aviation industry had been reduced, owing to non-state factors, such as market sentiments, pressure from local government groups, and travel needs brought about by foreign sectors.

China's airlines were once considered as the world's most unsafe (Dougan 2002). Due to the economic reformation process, the aviation industry expanded rapidly, where new entrants formed a large number of airlines. The reformations prior to the 2002 consolidation have led the industry into a situation where many new airlines, which are not under the direct control of the CAAC, have entered the industry. As a regulator of the industry, the CAAC was not capable of monitoring the safe operations of all airlines and other operational standards. 
The price deregulation in 1992 has caused repeated price wars between airlines. In addition, with the intense price war brought about by the increase competition from new market entrants, China's aviation industry suffered a combined loss of more than RMB 3 billion in 1998. The loss was due to the discounted airfares at an unsustainable level, even when passenger loads were high. This was mainly due to the airfare deregulation implemented by the CAAC, hoping to improve airlines' efficiency and to attract more passengers, by adopting the price discrimination system. Nonetheless, the demand in the transportation industry declined due to the Asian Financial Crisis between the period of 1997 and 1999.

Various policies have been carried out by the CAAC in order to solve the price war among airlines. However, CAAC's role as the industry regulator was being challenged. In February 1999, the strict policy implementation to prevent airlines' discounts to be any lower than 20 percent of its normal price was disregarded by most airlines. Price war continued and another cooperative revenue pooling policy was implemented, but it was abandoned later. The revenue pooling policy failed as it restricts the competition among airlines, which directly sacrifice the stronger airlines best interest to accommodate the weaker ones. Most airlines ignored the agreed discount range set. This caused the total number of passengers carried by China's aviation industry to exponentially grow in the early years after 2002 (Figure 1).

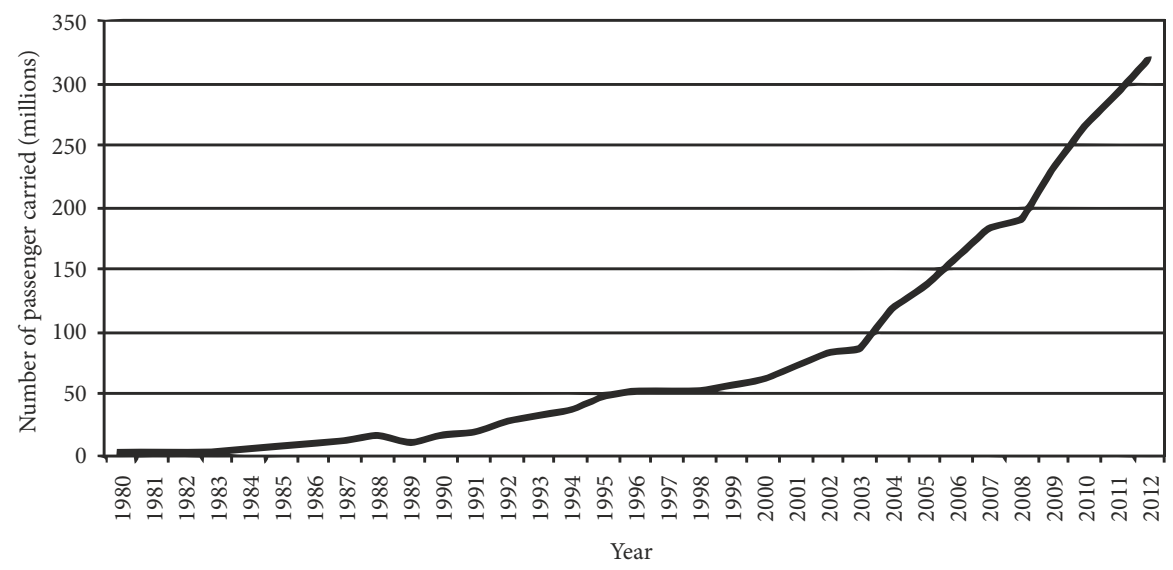

Figure 1. Passengers carried for China's aviation industry, 1980-2012 (source: The World Bank, 2016)

Although the CAAC no longer retains full control, it could still enforce policy changes in the aviation industry. The CAAC is more than the industry's regulator and safety authority; it decides the routes where local and foreign airlines can fly and also the development of the aviation industry. Since the year 2002, the CAAC had mandated that nine airlines affiliated to the CAAC be reduced into three major state-owned airline companies under a major Chinese aviation consolidation exercise (Figure 2) (Dougan 2002; Shaw et al. 2009). The consolidation provides CAAC with a means to regain better control over the industry, as well as improve the industry's overall profit. The three major groups were formed under the Civil Aviation System Reform Program, and were given a chance to buy or lease more aircraft. The Big Three comprising Air China, China Southern, and China Eastern Airlines 
is a consolidation effort to manage pricing, and to plan better concentration of routes for a broader market network (Zhang, Round 2011). Even though their operating costs may be relatively lower than the other regional airlines, they are all saddled with inefficiencies from the consolidation process, primarily AC with China Southwest Airlines; CS with China Northern Airlines; CE with Yunnan Airlines.

Since China applied to join the World Trade Organization (WTO) in the 1990s, the industry is preparing itself to face more intense competition. After 15 years of negotiation, China finally joined the WTO in December 2001 (Agarwal, Wu 2004). Due to the constant airfare reduction, the Big Three was formed (Zhang, Round 2009). The mergers that took place are expected to reduce the number of competitors and increase the competitiveness of the industry in a sustainable fashion, thus avoiding further price wars. This also suggests a market correction effort by the Chinese government to ease the outcome observed from its earlier liberalization, which saw major losses in the airline industry due to an initial intense direct competition. Competition outside of these three major carriers is considered to be negligible, where AC (28.9\%), CS (26.6\%), and CE (23.6\%) market shares in terms of revenue-passenger kilometres are added up to be approximately $79.1 \%$ in 2012 (Chiu 2013). By using the Lerner Index, Zhang et al. (2014) analysed the market power of the Big Three and showed that AC is the strongest, whereas CE is the weakest while CS is positioned in the middle. This provides an ideal representation of an oligopolistic airline market. According to Wang et al. (2014), it is relevant to represent the Big Three by the oligopolistic market structure, since they dominate the overall market, especially on the high demand air routes, even after new entrants were allowed into the industry.

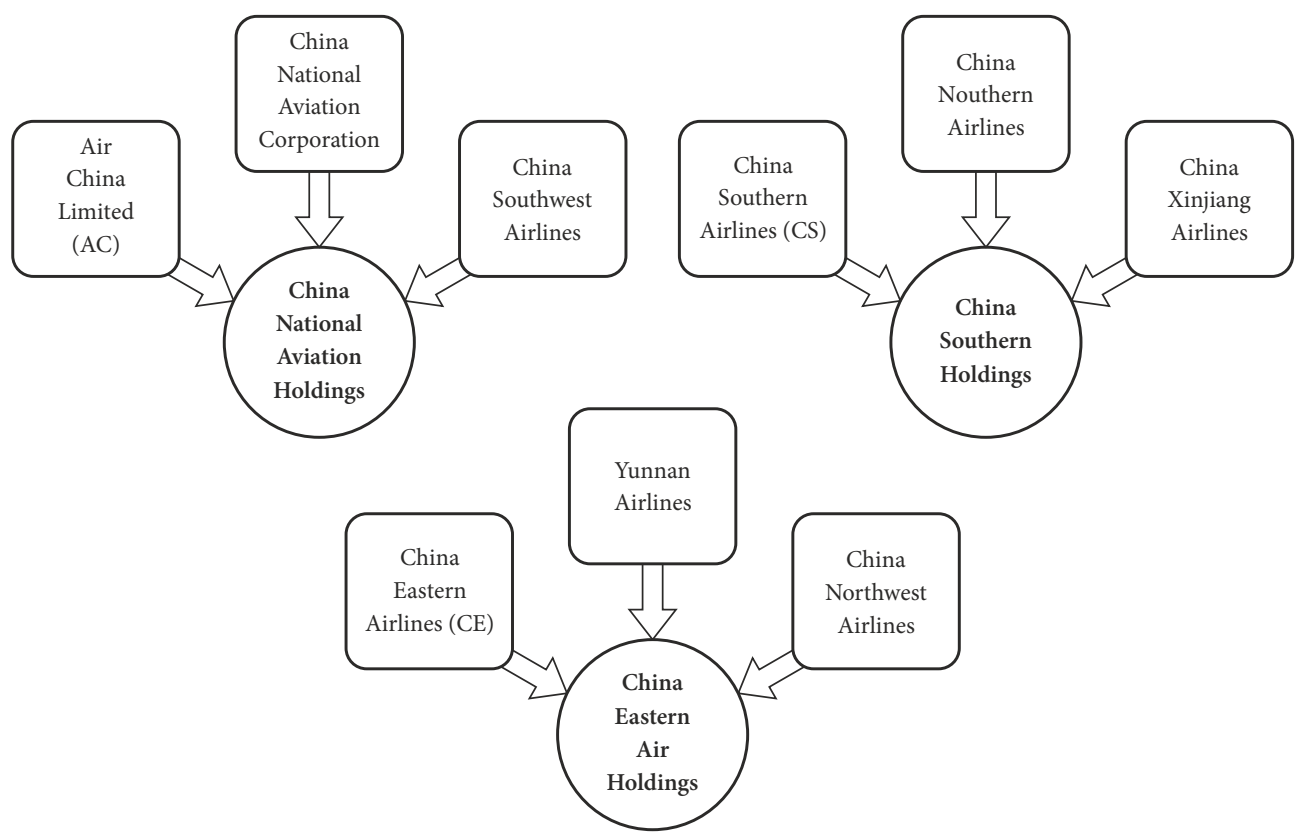

Figure 2. Nine smaller regional carriers forming the Big Three - China National Aviation Holdings, China Southern Holdings and China Eastern Air Holdings 
Price deregulation took place after the three merged groups became more established, which allowed airlines to freely decide on airfares and thus ended the government-controlled fare system. Therefore, we see the airline sector in China as an oligopolistic market structure, where the balance between the two extreme market structures of perfect competition and monopoly lies. The consolidation process in 2002 is a natural response to the changes that accompanied airline deregulation in China (Cao et al. 2015; Zhang, Round 2008).

In 2005, CAAC allowed non-state-owned enterprises, individuals, and also foreign capitals to invest in the civil aviation industry. Through deregulation, CAAC also allowed new entrants to the industry, which includes Hainan Airlines that has later grown its business into the fourth largest airline in China. There are two main reasons where Hainan Airlines is not included in this study. First, it is due to the different nature between Hainan Airline's point-to-point flight operation and the Big Three's hub-and-spoke flight operation. Second, Hainan Airlines serve as an independent airline without being owned and controlled by the state (Peng 2010). However, due to the increasing competition, CAAC suspended the establishment of new airlines in 2007, while investments were still encouraged.

Zhang and Round (2008) provides further discussion on the evolution of China's airline industry, specifically during the deregulation stage, after the airline consolidation occurred. Albeit the initiated merger by the CAAC, inter-airline competition still exists, and airlines still remain concern over potential future price wars.

Empirical study conducted by Fu et al. (2015) examining the competition effects brought by Spring Airlines (a low cost carrier that entered into the industry in 2005) on four largest Chinese airlines, including the state-owned Big Three and Hainan Airlines suggested that low cost carriers in China carry the role of potential competitors in the market, but yet to be considered a major threat. The Big Three is believed to be able to maintain their competitiveness in the industry with the support of the government capital injection and fuel supply that has been monopolised by a state-owned company, China Aviation Fuel. Aside from the RMB 10 billion capital injection received by CE in 2009, AC, CS, and CE received RMB 2 billion, RMB 1 billion, and RMB 3 billion from the government in 2012, respectively.

However, Cao et al. (2015) suggests that the Chinese government should reduce its support to the state-owned Big Three to create a fair and healthy competition platform for the aviation industry. This is because the improved efficiency rate of non-state-owned airlines had begun to exceed the state-owned airlines after the industry deregulation. There are two main reasons that lead to the inefficiency of most state-owned enterprises (including airlines) (Mar, Young 2001). First, the low incentive for the bureaucrat to monitor the firms' performance because firms are neither being rewarded nor penalized based on their performance outcome. Second, the appointment of managers is often politically motivated rather than their qualifications in the relevant field.

Many research questions surfaced following the Big Three consolidation and the industry deregulation processes. This paper considers a 3-player Cournot model to assess the competition among the three major airlines. We seek to investigate the effect differences in the pre-and-post merger initiative, which accounts for the post deregulation process that took place in 2005. Studies of the changes before and after the consolidation decision made by the CAAC to form the Big Three can shed light on the current status and future prospects of the Chinese aviation industry. 
The Big Three enjoys relatively higher profitability as compared to other major airlines, in spite of their lower productivity (Wang et al. 2014). Besides that, there are also several research that focus on analysing the effects of the industry deregulation on the efficiency of Chinese airlines (Cao et al. 2015; Chow 2010; Chow, Fung 2012; Zhang, Round 2008). Chow and Fung (2012) analysed the productivity changes of state-owned airlines after the $\mathrm{M} \& A s$ process and claim that AC was the major beneficiary of the merger process, CS made progress in terms of productivity development, while CE shows no productivity growth. However, up-to-date literatures show none of the research conducted uses the game theoretic analysis. This paper intends to fill the research gap within the Chinese aviation industry, in analysing the Big Three consolidation effects before and after the 2005 deregulation process.

The main purpose of this research is to analyse the effects of the M\&As on the airlines' profitability and to provide justification on whether the decision made by the CAAC brings positive or negative effects to the industry and the three respective airlines on top of the industry deregulation. Section 1 provides the literature in the relevant areas of the aviation sector, M\&As, and the applied game theoretic models. Section 2 introduces the Cournot game models for the Chinese airline industry. Section 3 presents the results under the eight different scenarios for the Cournot models and last section concludes.

\section{Literature review}

\subsection{Mergers and acquisitions (M\&As)}

Industry deregulation, which removed or loosened the price and entry restriction in an industry, usually leads to intense competition among firms, which ultimately reduces the carriers' total profit (Lin 2008). Nonetheless, it presents opportunities for industry consolidation, either to minimize further risk exposure or exploit complementarities between coexisting carriers. The global aviation industry scene shows the relationship between industry deregulation and the surge in consolidation among firms, such as the U.S. (1978), Canada (1984), New Zealand (1986), Australia (1990), and Europe (1992-1997) (Gillen, Morrison 2005). From a country's perspective, industry deregulation takes effect when it is poised to survive under intense competition from both domestic and foreign firms. In the case of the U.S. airline industry, price and entry regulation processes were initially expected to improve the domestic airlines' financial status. Nonetheless, the intense competition that follows deregulation forced many airlines to cease operations, with some undertaking an M\&A strategy to benefit from operating a large hub-and-spoke network (Kole, Lehn 1999).

Hence, airline mergers do not necessary guarantee improvement in profitability and efficiency. Mergers between two different airline cultures, America West and US Airways, showed integration process difficulties, even though there is no drop in share value (Tahmincioglu 2006). The difficulties brought by a merger were possibly due to pilot salary and seniority issues, work rules, and worker union representative issues (Boru 2006; Miles, Mangold 2005).

The objectives of the M\&As are mainly to gain a larger market share, to improve a firm's efficiency, and/or to be competitively placed against new market entrants (Kumar, Bansal 2008). Although a firm's intent for engaging in an M\&A strategy is to gain positive impact 
on performance, M\&As do not often lead to an absolute performance improvement, judging by some reported negative effects. The survey conducted by Tichy (2001) showed that about half of the mergers were found to have their firms' value reduced. Adler and Smilowitz (2007) claimed that some mergers might be more successful than others, depending on the number of competitors remaining in the market. Interestingly, Clougherty and Duso (2009) discovered that when competitors merge, rivals are more likely to experience gains. More pricing power will be distributed among firms when the number of competitors in the industry has been reduced.

Nonetheless, there is an extant literature covering M\&As and their positive influences across various fields. The behavioural and neoclassic hypothesis tests indicate that regulatory and economic shocks together with capital liquidity are major causes to merger waves from the 1980s to the 1990s (Harford 2005). Post-merger operating performance was claimed to remain unchanged or better during the observed period.

M\&As are common strategies for firms to improve their competitiveness in emerging markets. In Asia, for instance, financial restructuring after the Asian financial crisis has caused a surge in M\&A activities among Korean commercial banks. Two mega-banks were established in 2002 during the restructuring process, resulting in increased market concentration. Nonetheless, continuous market concentration was unable to lessen the industry's intense competition (Park 2009). Kumar and Bansal (2008) analysed pre-and-post merger effects on 74 M\&A cases in India through a 6-year time horizon, and concluded that synergy was established through higher cash flows, diversification, and cost cutting measures. Specifically, in 52 acquisition deals, 60 percent registered higher financial performance during the post-merger period.

A successful alliance increases the firms' value through economies of scale and scope, market share, overall competitiveness (Evans 2001; Kumar, Bansal 2008), experience and pricing power (Clougherty, Duso 2009). In the case of the Big Three, the consolidation effort was an attempt to reduce the number of airlines operating in the industry, which led to a less intense market environment, thus preventing unnecessary price war among airlines.

The motives for consolidation of the Big Three have been broadly discussed by Zhang and Round (2008). They explained that the world's airline mergers and alliances trend are caused by the main reasons of market share expansion and financial improvement. With regards to the airline industry in China, price wars still persist after the 2002 consolidation, albeit not as frequent. The Big Three (Air China, China Southern, and China Eastern) managed the price war effects better due to their larger networks. Price wars are typically started by airlines with a relatively smaller market share and poor load factors. The monthly data on airfares from the period of 2002 to 2004 revealed that merger activities did not bring down the price wars (Honert, Stewart 1992).

The number of airlines was reduced throughout the consolidation process in order to reduce the intensity of market competition among the airlines. However, the number of airlines was later increased again when China allowed new entrants into the industry. The market competition index analysis shows that the China aviation industry's competitiveness still remain intact (Wang et al. 2014). The overall China's aviation industry deregulation process was believed to serve the purpose of protecting its growing domestic market, by creating and strengthening the domestic airlines (the Big Three), before competing internationally. 


\subsection{Game theory in M\&As and strategic alliances}

A full Nash-Kalai model and three simplified models have been applied to a sample of 24 M\&As listed on the Johannesburg Stock Exchange (Honert, Stewart 1992). It was one of the earliest game theoretic works on M\&As, where a parsimonious descriptive model, consisting of both targets and acquirers during merger negotiations was constructed. The research results indicate that only one of the four models tested (the fixed $\gamma$ Nash-Kalai model) is more efficient and improves on the earlier full model in terms of obtaining solutions to the merger problem.

Artz et al. (2009) applied the Cournot-Nash model and two-stage game backward induction method into the mixed oligopoly model. They show that mergers between private and public firms, defined as mixed oligopoly, will always increase the profit and welfare of both parties, which ultimately lead to privatization.

Stackelberg models have been used to analyze the economic effects of code-sharing alliances between an international and a domestic airline, and for choosing the role between a fare-leader and a fare-follower. Research has proven that there exist two types of Stackelberg equilibria when allied and unallied airlines can endogenously choose to either be a fare-leader or a fare-follower (Lin, 2004). When the degree of product differentiation in the duopoly market is large, the equilibrium shows that an allied airline should act as the leader, while the unallied airline should act as a follower. The reverse holds in the case of low product differentiation. However, Stackelberg leader-follower model presents a sequential decision making model, which is not suitable to be apply in our scenarios. The industry consolidation decisions are ultimately controlled and decided by the CAAC - the regulator in the aviation industry.

Barbot (2009) developed a model to analyse the incentives for the airport-airline vertical collusion. The competition is between one airport-airline formation and another. Bertrand competition models reveal that airlines prefer not to collude under market and quality symmetry airports. Both airline and airport agree to collude when the airlines are vertically differentiated, and the difference between their marginal costs is large.

A game-theoretic model had been applied to corporate takeovers by major shareholders. Powers (1987) showed that in the event of only two symmetric major shareholders with the same amount of decision power, only one of them would end up gaining control over the company. By assuming it as an oceanic game, minor players have been instrumental in affecting the company's decision-making process.

Fan et al. (2001) explore the literature on alliances and the motivations for alliance formation. They find that globalization, regionalization, economics, regulatory regime, and anti-trust are the five major forces considered by firms when forming a pact. A successful alliance would increase the firm's value through economies of scale, scope, and enhancement of their competitiveness. Firms that remain over reliant on other partners in the alliance are considered as failures to the alliance (Evans, 2001).

Lin (2008) investigates the role of code-sharing alliances on entry deterrence by using the Bertrand-Nash model to solve the standard profit maximization problems. The degree of product differentiation degree and network size may affect a carrier's profit. Network size and a carrier's profit are positively related, in that a large network size will see its profit reduced if the degree of product differentiation is small. 


\section{The model}

In this study, we consider a 3-player Cournot oligopoly game model, and present the model under eight possible scenarios (see Figure 3). Three basic elements need to be defined prior to applying a game theoretic model in strategic decision-making. These are the players, strategy set, and payoffs. Based on these factors, we define a game consisting of three major Chinese airlines, $\mathrm{AC}, \mathrm{CE}$, and CS, with a strategy set of non-negative quantities in terms of the passengers carried that each airline can choose from $\mathfrak{R}^{+} \cup\{0\}$.

The year after 2005 is consider as the post deregulation process for the aviation industry (Chow 2010). Since the full integration of the assets of the merging parties from the consolidation process was formally completed in 2005, we consider the strategy sets for each airline such that the following two periods are defined for analyzing the strategic interactions in a 3-player sequential game model:

Pre M\&A The earlier stages of China's airline industry reform since the formation of the Big Three, (2003-2005) but before the end of the consolidation process.

(The 3-year period before the industry deregulation in 2005)

Post M\&A The later stages of consolidation, with some completed M\&A deals by the Big Three, i.e. (2006-2010) AC (8 deals), CS (4 deals), and CE (4 deals).

(The 5-year period right after the industry deregulation in 2005)

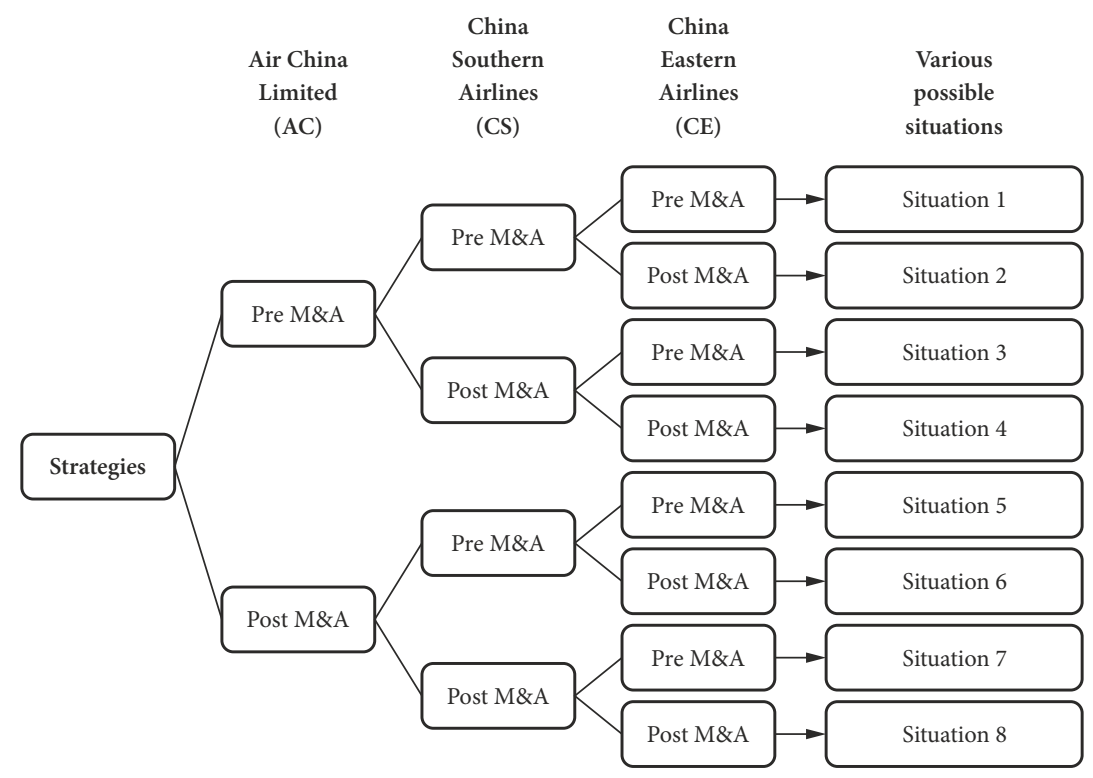

Figure 3. Eight scenarios for Cournot model analysis 
Table 2 shows the outline of the notations used in this paper.

Table 2. List of mathematical symbols and notations

\begin{tabular}{|c|l|}
\hline$i$ & Index $(i=1,2,3)$ represents AC, CS, and CE, respectively \\
\hline$q_{i}$ & Airline $i$ 's passenger carried \\
\hline$q_{-i}$ & Other airlines' total passenger carried, except $i$ \\
\hline$q_{i}^{C}$ & Airline $i$ 's optimal passenger to be carried \\
\hline$Q$ & Total passenger carried by all three airlines \\
\hline$\pi_{i}^{t}$ & Airline $i$ 's profit function (RMB billion) of period $t$ \\
\hline$\pi_{i}^{C}$ & Airline $i$ Cournot model's optimal profit (RMB billion) \\
\hline$T R_{i}^{t}$ & Airline $i$ 's revenue function (RMB billion) of period $t$ in terms of $Q$ \\
\hline$T C_{i}^{t}$ & Airline $i$ 's operating expenses function (RMB billion) of period $t$ in terms of $q_{i}$ \\
\hline$t$ & Periods representing pre and post M\&A and industry deregulation \\
\hline$a_{j_{-} i}$ & Coefficient of the $j^{\text {th }}$ degree of variables $Q^{j}$ in the total revenue quadratic functions for airline $i$ \\
\hline$b_{j_{-} i}$ & Coefficient of the $j^{\text {th }}$ degree of variables $q_{i}^{j}$ in the total cost quadratic functions for airline $i$ \\
\hline$j$ & Degree level of both variables $Q{ }^{j}$ and $q_{i}^{j}$ \\
\hline
\end{tabular}

\subsection{Cournot model}

The CAAC enforced that nine of its controlled airlines merge into three in its aviation sector's consolidation effort. This consolidation can be seen as a perfect information Cournot oligopoly game model, which provides a suitable framework for investigating the effects of the consolidation before and after the industry deregulation. It assumes that each firms in the sector determines the output level simultaneously under a perfect information situation. Firms compete in terms of quantities and they are rational while making their respective decision.

We assume that the three airlines produce homogeneous services, with no new entrants. Next, the decision variables used are the number of passengers carried by each airline and the total passenger count for the industry. Third, we assume that, similar to the other market structures, airlines seek to maximize profit and minimize cost. The descriptive statistics for Total Revenue, Total Cost and Number of Passengers carried for the 3 airlines before and after the merger waves are provided in Table 3 . The values are aggregated through each of the respective airline's annual report.

The best fit line (based on a quadratic fitted model) for the relationship between air passenger revenue and number of passengers carried, and the relationship between operating expenses and the number of passengers carried gives us the revenue and cost functions, respectively. The profit functions for $\mathrm{AC}, \mathrm{CS}$, and $\mathrm{CE}$ for both pre-and-post M\&A situations 
Table 3. Descriptive statistics

\begin{tabular}{|c|l|c|c|c|c|}
\hline \multirow{2}{*}{ Airlines } & \multicolumn{1}{|c|}{ Descriptions } & \multicolumn{2}{|c|}{ Pre-M\&A } & \multicolumn{2}{c|}{ Post-M\&A } \\
\cline { 3 - 6 } & & Mean & Standard Deviation & Mean & Standard Deviation \\
\hline \multirow{4}{*}{ AC } & $\begin{array}{l}\text { Total Revenue } \\
\text { (RMB million) }\end{array}$ & 25261.26 & 6794.759 & 46991.72 & 11805.54 \\
\cline { 2 - 6 } & $\begin{array}{l}\text { Total Cost } \\
\text { (RMB million) }\end{array}$ & 19882.16 & 6307.37 & 42151.64 & 9828.38 \\
\cline { 2 - 6 } & Passenger Carried ('000) & 73048.55 & 23908.73 & 147227.54 & 32527.24 \\
\hline \multirow{5}{*}{ CS } & $\begin{array}{l}\text { Total Revenue } \\
\text { (RMB million) }\end{array}$ & 23433.32 & 9702.95 & 52317.87 & 10046.42 \\
\cline { 2 - 6 } & $\begin{array}{l}\text { Total Cost } \\
\text { (RMB million) }\end{array}$ & 12165.56 & 7002.84 & 43039.72 & 8507.30 \\
\cline { 2 - 6 } & Passenger Carried ('000) & 73048.55 & 23908.73 & 147227.54 & 32527.24 \\
\hline \multirow{3}{*}{ CE } & $\begin{array}{l}\text { Total Revenue } \\
\text { (RMB million) }\end{array}$ & 15481.24 & 5237.79 & 38212.18 & 11570.91 \\
\cline { 2 - 6 } & $\begin{array}{l}\text { Total Cost } \\
\text { (RMB million) }\end{array}$ & 8604.07 & 4813.59 & 36601.80 & 10874.62 \\
\cline { 2 - 6 } & Passenger Carried ('000) & 73048.55 & 23908.73 & 147227.54 & 32527.24 \\
\hline
\end{tabular}

can be derived from the revenue function less operating expenses function. Both the revenue and cost functions are assumed quadratic as follows:

$$
\begin{aligned}
& T R_{i}^{t}=a_{2 \_i} Q^{2}+a_{11_{-} i} Q+a_{0 \_i} ; \\
& T C_{i}^{t}=b_{2 \_i} q_{i}^{2}+b_{1 \_i} q_{i}+b_{0{ }_{-} i} .
\end{aligned}
$$

As each airline's payoff is affected by its choice of strategy and that of the others, airline $i$ 's payoff function can be described as a profit function.

$$
\pi_{i}^{t}=T R_{i}^{t}-T C_{i}^{t}
$$

For simplicity, we reduce the profit function in period $t$ to

$$
\pi_{i}^{t}=\left(a_{2 \_i}-b_{2_{-} i}\right) q_{i}^{2}+\left(2 a_{2_{-} i} q_{-i}+a_{1_{-} i}-b_{1_{-} i}\right) q_{i}+\left(a_{2_{-} i} q_{-i}^{2}+a_{1_{-} i} q_{-i}+a_{0 \_i}-b_{0_{-} i}\right),
$$

where $Q=\sum q_{i}=q_{i}+q_{-i}$ and $t=P R E$, POST that indicates the period of pre and post M\&A, respectively.

The outcome of estimating equations (1), (2), and (4) can be observed in Table 4.

Differentiating each firm's profit functions yields the necessary condition for optimality

$$
\frac{\partial \pi_{i}^{t}}{\partial q_{i}}=2\left(a_{2_{-} i}-b_{2_{-} i}\right) q_{i}+\left(2 a_{2_{-} i}+a_{1_{-} i}-b_{1_{-} i}\right)=0 .
$$

The best response function is thus

$$
q_{i}=\frac{b_{1_{-} i}-2 a_{2_{-} i} q_{-i}-a_{1_{-} i}}{2\left(a_{2 \_}-b_{2_{-} i}\right)} .
$$


Table 4. Pre and Post M\&As revenue, cost, and profit functions for the Big Three

\begin{tabular}{|c|l|l|}
\hline $\begin{array}{c}\text { Air- } \\
\text { lines }\end{array}$ & \multicolumn{1}{|c|}{ Pre M\&A } & \multicolumn{1}{c|}{ Post M\&A } \\
\hline \multirow{4}{*}{$\mathrm{AC}$} & $T R_{1}^{P R E}=-0.000004 \cdot Q^{2}+0.9342 \cdot Q-17979$ & $T R_{1}^{P O S T}=0.000003 \cdot Q^{2}-0.6707 \cdot Q+74931$ \\
\cline { 2 - 4 } & $T C_{1}^{P R E}=0.00003 \cdot q_{1}^{2}-0.4461 \cdot q_{1}+11393$ & $T C_{1}^{P O S T}=0.00004 \cdot q_{1}^{2}-2.6387 \cdot q_{1}+87172$ \\
\cline { 2 - 4 } & $\pi_{1}^{P R E}=-0.000004 \cdot Q^{2}-0.00003 \cdot q_{1}^{2}+1.3803 \cdot q_{1}+$ & $\pi_{1}^{P O S T}=0.000003 \cdot Q^{2}-0.00004 \cdot q_{1}^{2}+1.9680 \cdot q_{1}-$ \\
& $0.9342 \cdot q_{2}+0.9342 \cdot q_{3}-29372$ & $0.6707 \cdot q_{2}-0.6707 \cdot q_{3}-12241$ \\
\hline \multirow{4}{*}{$\mathrm{CS}$} & $T R_{2}^{P R E}=0.000003 \cdot Q^{2}-0.0786 \cdot Q+10796$ & $T R_{2}^{P O S T}=0.0000005 \cdot Q^{2}+0.1239 \cdot Q+21997$ \\
\cline { 2 - 4 } & $T C_{2}^{P R E}=0.000002 \cdot q_{2}^{2}+0.6120 \cdot q_{2}-2721$ & $T C_{2}^{P O S T}=0.000002 \cdot q_{2}^{2}+0.4699 \cdot q_{2}+5864$ \\
\cline { 2 - 4 } & $\pi_{2}^{P R E}=0.000003 \cdot Q^{2}-0.000002 \cdot q_{2}^{2}-0.0786 \cdot q_{1}-$ & $\pi_{2}^{P O S T}=0.0000005 \cdot Q^{2}-0.000002 \cdot q_{2}^{2}+0.1239 \cdot q_{1}-$ \\
& $0.6906 \cdot q_{2}-0.0786 \cdot q_{3}+13517$ & $0.3460 \cdot q_{2}+0.1239 \cdot q_{3}+16133$ \\
\hline \multirow{4}{*}{$\mathrm{CE}$} & $T R_{3}^{P R E}=-0.000001 \cdot Q^{2}+0.4399 \cdot Q-8204.1$ & $T R_{3}^{P O S T}=0.000005 \cdot Q^{2}-1.1509 \cdot Q+104576$ \\
\cline { 2 - 4 } & $T C_{3}^{P R E}=-0.000003 \cdot q_{3}^{2}+0.9861 \cdot q_{3}-2921.2$ & $T C_{3}^{P O S T}=0.00005 \cdot q_{3}^{2}-4.5957 \cdot q_{3}+131086$ \\
\cline { 2 - 4 } & $\pi_{3}^{P R E}=-0.000001 \cdot Q^{2}+0.000003 \cdot q_{3}^{2}+0.4399 \cdot q_{1}+$ & $\pi_{3}^{P O S T}=0.000005 \cdot Q^{2}-0.00005 \cdot q_{3}^{2}-1.1509 \cdot q_{1}-$ \\
& $0.4399 \cdot q_{2}-0.5462 \cdot q_{3}-5282.9$ & $1.1509 \cdot q_{2}+3.4448 \cdot q_{3}-26510$ \\
\hline
\end{tabular}

The profit maximizing conditions for each airline in the two different periods are obtained by differentiating their profit functions, $\pi_{i}^{t}$ with respect to their quantity, $q_{i}$. The best response functions for each airline are then illustrated in Table 5.

Table 5. Pre and Post M\&As best response functions for the Big Three

\begin{tabular}{|c|c|c|}
\hline \multirow{2}{*}{ AC } & Pre M\&A & $q_{1}=-0.117647 \cdot q_{2}-0.117647 \cdot q_{3}+20298.53$ \\
\cline { 2 - 3 } & Post M\&A & $q_{1}=0.081081 \cdot q_{2}+0.081081 \cdot q_{3}+26594.59$ \\
\hline \multirow{2}{*}{ CS } & Pre M\&A & $q_{2}=-3.000000 \cdot q_{1}-3.000000 \cdot q_{3}+345300.00$ \\
\cline { 2 - 3 } & Post M\&A & $q_{2}=0.333333 \cdot q_{1}+0.333333 \cdot q_{3}-115333.33$ \\
\hline \multirow{2}{*}{ CE } & Pre M\&A & $q_{3}=0.500000 \cdot q_{1}+0.500000 \cdot q_{2}+136550.00$ \\
\cline { 2 - 3 } & Post M\&A & $q_{3}=0.111111 \cdot q_{1}+0.111111 \cdot q_{2}+38275.56$ \\
\hline
\end{tabular}

The best response functions are paired according to the eight various situations shown previously. The optimal quantities, $q_{i}^{C}$ for each airline are obtained by using the simultaneous equations method to solve each of the best response functions accordingly. Next, the quantities obtained, $q_{i}^{C}$ are used to substitute into the profit functions, $\pi_{i}^{t}$ in order to obtain the optimal profits $\pi_{i}^{C}$. The next section discusses the results obtained from the model. 


\section{Results and discussion}

In this section, we present the analytical results for the eight scenarios under the Cournot model. The Cournot oligopoly game model presents a simultaneous decision making model under perfect information, where players will select a strategy to maximize their profits. Eight scenarios have been analyzed to select the best strategy for each firm.

In order to speed up the consolidation process, the CAAC prohibited airlines from operating between cities where they do not use as hubs. This policy made it difficult for the regional airlines to survive, and forced them to merge with one of the Big Three, while some were taken over by Hainan Airlines. In 2005, the consolidation process of the Big Three was formerly completed. Upon the completion of the consolidation process, the CAAC and the state no longer fully control the airlines. Neither group possessed an absolute advantage over the others as each group had their own base and were assigned large regional hubs to serve important gateway cities (see Table 1) (Dougan, 2002). The CAAC mandated this move by identifying individual airlines with complementary route structures to be consolidated with AC, CE, and CS, respectively. Such strategically designed decision was made to simply minimize major adjustments to the merged airlines while expanding their networks, thus minimizing direct competition among the Big Three (Shaw et al. 2009).

To apply the Cournot game model in our analysis, we first determine all the airlines' best response functions by differentiating each profit function with respect to the passengers carried. By considering the case of Situation 1, the best response functions, $q_{1}, q_{2}$, and $q_{3}$ obtained for the pre M\&A period are to be grouped together and solved simultaneously in obtaining the optimal passenger carried, $q_{1}^{C}, q_{2}^{C}$, and $q_{3}^{C}$. Similar calculation steps were applied to each of the following scenarios mentioned earlier. By substituting the optimal number of passengers carried into each firm's profit function, Figure 4 gives us the values for all the payoffs. Specifically, the decision-tree in Figure 4 depicts the relationship among the 3 airlines whose decision and payoffs are inter-related. The results indicate that, under the Cournot oligopoly game model, AC, CS, and CE all are better off in terms of the profit gained after the consolidation's M\&A and the industry deregulation processes.

Recent literature in the airline industry focuses on the application of data envelopment analysis (DEA) or/and Malmquist productivity index (Cao et al. 2015; Chow 2010; Chow, Fung 2012; Fu et al. 2015) in analysing the productivity of various Chinese airlines after the industry deregulation in 2005. However, these research do not take into account the strategic moves each airline took to shape the whole structure of the aviation industry. To the best of our knowledge, research that applied game theory in analysing the Big Three has yet to be undertaken. Game theory has been widely applied in analysing strategic decision-making situations among individuals, in which each player's decision will affect one another and also themselves. In particular, Cournot oligopoly game model was chosen in this case as its modelling assumptions fits well with the Big Three consolidation process.

Cournot model is suitable for oligopolistic market structure in which firms produce homogeneous products or services, and compete in terms of quantity. The industry consolidation mandated by the CAAC can be viewed as a simultaneous move game. In fact, the pricing in the Chinese aviation industry is regulated by the CAAC. Hence, the airlines compete in terms of quantity, i.e. total number of passengers carried. 


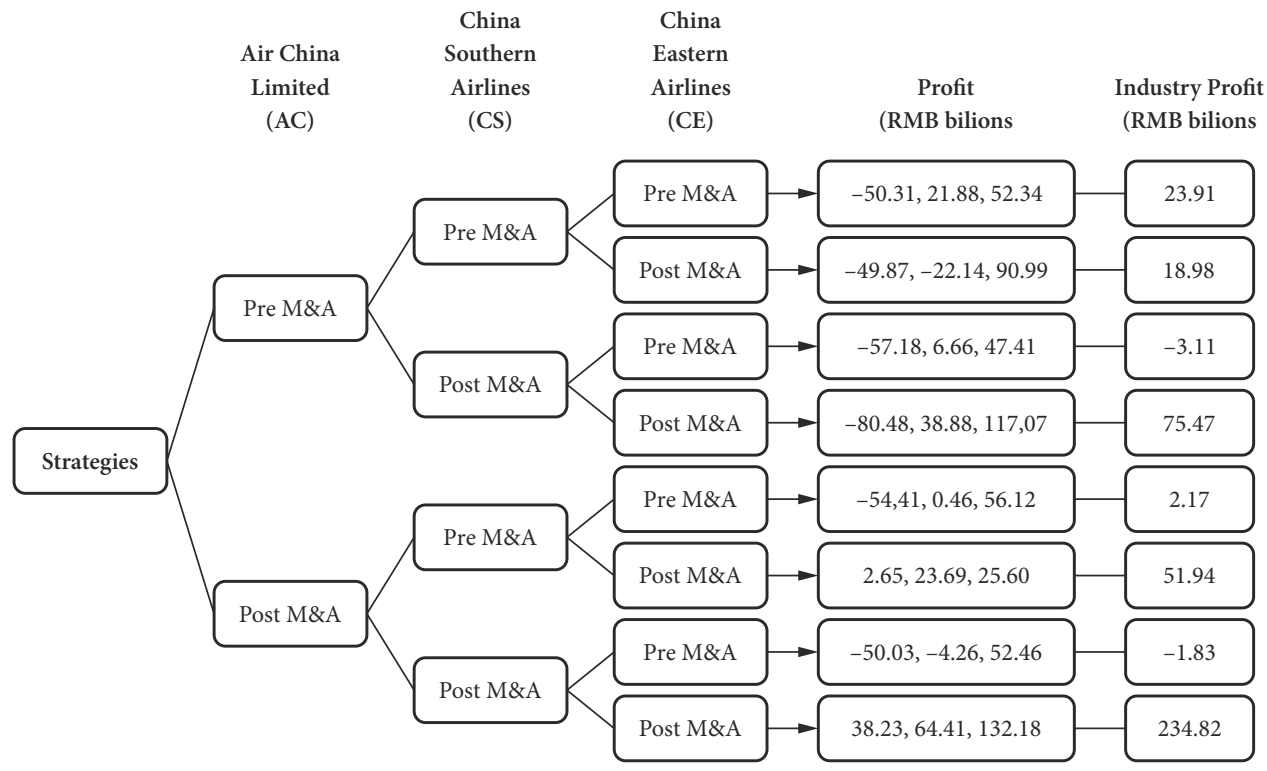

Figure 4. Optimal profit for AC, CS, CE and the aviation industry under Cournot model

Figure 4 illustrates that the Big Three are better off in terms of the profit gained after the M\&A and the industry deregulation process. However, according to Tahmincioglu (2006), airline mergers may not lead to profitability improvement. The Big Three's total passengers carried rose, but the profit earned from carrying travellers per kilometre fell due to the intense competition by newly established low cost carriers - Spring Airlines and Juneyao Airlines (Bloomberg, 2016). On average, the combined return of the Big Three is just onethird of Spring Airlines and Juneyao Airlines.

Despite the smaller sizes of Spring Airlines and Juneyao Airlines, they are able to offer cheaper airfares, more cost-efficient and profit-driven, as well as not possessing any baggage of legacy. Therefore, there is further room for improvement for the Big Three in terms of achieving better productivity (Wang et al. 2014).

Following the Cournot model, we assume that competition only happens among the Big Three without forces imposed by new entrants to the industry. In reality, market structure changes over time. However, this does render the applicability of the Cournot model in this case to be questionable. On the contrary, the results of the model show positive profitability and increasing total number of passengers carried after the consolidation process. In order to gain a better insight, future research should consider factors such as fuel price and currency exchange on travel patterns.

\section{Conclusions}

Since 2005, China's aviation industry showed rapid growth and ranked second, just behind the United States. Chinese aviation industry plays a prominent role in the Chinese economy, and is now among the most profitable airlines in the world. This paper examines the perfor- 
mance of China's 3 dominant airlines, AC, CS and CE, subsequent to the major consolidation process that started in 2002, and completed in 2005, together with the industry deregulation implementation. The Cournot oligopoly models are used to assess the pre-and-post M\&A strategies for the 3 airlines. We find that all airlines were better off after the acquisition exercise on top of the industry deregulation. This suggests that M\&A activities in the industry deregulation process may be one of the best solutions in addressing China's aviation industry problems in the long run.

However, Wang et al. (2014) claimed that the deregulation efforts are rather "incomplete" and there are spaces for further improvement in terms of achieving better productivity. Therefore, it was suggested that instead of protecting the state-owned central airlines, China's government should withdraw from direct intervention of aviation management (especially the Big Three aviation groups), while developing policies that allow for a more well developed competition environment among the civil aviation industry. Future research may want to investigate the effects of intervention removal by the Chinese Government and whether performance will resort back to the price war condition or there is further improvement to be gain.

Further research may include the effects of some unexpected incidents, such as the Sept. 11 terrorist attacks in the U.S., and also the two consecutive aircraft crashes that happened within a month. China was affected the worse by the severe acute respiratory syndrome (SARS) outbreak, which killed 774 people out of the 8,098 infected. Future research may investigate low probability-high impact events and their effect on airline profitability and performance. The recent establishment of China's high-speed railway that connects Beijing and Shanghai while reducing the travelling time from 14 hours to just four hours posed a competition to the airline industry. Both complementary and competitive effects from the wholly government-owned rail operations to the partially privatized airlines could also be included in future studies.

Future research on game theory may include other non-conventional factors such as service quality attributes in their strategic planning analysis, rather than the prevalent quantity served and pricing factors. To date, the methodology that dominates M\&A studies is mostly drawn from event studies. Thus, it is understandable that researchers resort to conventional statistical tools where panel data analyses are used in such studies. Nonetheless, what is less understood in M\&A studies are whether the strategic decisions that were taken remain an optimal decision. Are there other ways that the strategy can be constructed and disseminated to reverse the role of players that could be a win-win situation for all? Without strategic interaction integrated into M\&As, the findings of such studies may not be directly generalizable. For example, event studies that conduct a pre-and-post study may note the changes on the variables across the two periods, without insights into how one player's move affects another in the overall context. This is particularly more challenging in the aviation sector, given that the industry growth is usually acting in a cyclical manner. Thus, studies on M\&As should consider the pattern of growth of the industry, and illustrate clearly the strategic interaction of the players in the pattern. Given that China's aviation sector has strong domestic growth, this is an initial M\&A study on the domestic front. It is highly possible that market pressures and the constant need for a large global airline may force a next merger wave in the aviation sector. 


\section{References}

Adler, N.; Smilowitz, K. 2007. Hub-and-spoke network alliances and mergers: price-location competition in the airline industry, Transportation Research Part B 41: 394-409. https://doi.org/10.1016/j.trb.2006.06.005

Agarwal, J.; Wu, T. 2004. China's entry to WTO: global marketing issues, impact, and implications for China, International Marketing Review 21(3): 279-300. https://doi.org/10.1108/02651330410539620

Artz, B.; Heywood, J. S.; McGinty, M. 2009. The merger paradox in a mixed oligopoly, Research in Economics 63: 1-10. https://doi.org/10.1016/j.rie.2008.10.003

Barbot, C. 2009. Airport and airlines competition: incentives for vertical collusion, Transportation Research Part B 43: 952-965. https://doi.org/10.1016/j.trb.2009.04.001

Bloomberg. 2016. Without legacy China Budget Airlines Gain on "Big Three". Bloomberg News [online], [cited 10 July 2016]. Available from Internet: http://www.bloomberg.com/news/articles/2016-03-30/ without-legacy-baggage-china-budget-airlines-gain-on-big-three

Boru, B. 2006. Ryanair: the Cú Chulainn of civil aviation, Journal of Strategic Marketing 14(1): 45-55. https://doi.org/10.1080/09652540500511420

Cao, Q.; Lv, J.; Zhang, J. 2015. Productivity efficiency analysis of the airlines in China after deregulation, Journal of Air Transport Management 42: 135-140. https://doi.org/10.1016/j.jairtraman.2014.09.009

Chiu, J. 2013. China's air regulator will consider ways to boost budget-carrier market [online], [cited 5 March 2016]. Available from Internet: http://www.wsj.com/articles/SB10001424127887323854904 578634920047272886

Chow, C. K. W. 2010. Measuring the productivity changes of Chinese airlines: the impact of the entries of non-state-owned carriers, Journal of Air Transport Management 16(6): 320-324. https://doi.org/10.1016/j.jairtraman.2010.04.001

Chow, C. K. W.; Fung, M. K. Y. 2012. Measuring the effects of China's airline mergers on the productivity of state-owned carriers, Journal of Air Transport Management 25: 1-4. https://doi.org/10.1016/j.jairtraman.2011.08.006

Clougherty, J. A.; Duso, T. 2009. The impact of horizontal mergers on rivals: gains to being left outside a merger, Journal of Management Studies 46(8): 1365-1395. https://doi.org/10.1111/j.1467-6486.2009.00852.x

Dougan, M. 2002. A political economy analysis of China's civil aviation industry. New York, USA and London, UK: Routledge.

Evans, N. 2001. Collaborative strategy: an analysis of the changing world of international airline alliances, Tourism Management 22(3): 229-243. https://doi.org/10.1016/S0261-5177(01)00024-3

Fan, T.; Vigeant-Langlois, L.; Geissler, C.; Bosler, B.; Wilmking, J. 2001. Evolution of global airline strategic alliance and consolidation in the twenty-first century, Journal of Air Transport Management 7(6): 349-360. https://doi.org/10.1016/S0969-6997(01)00027-8

Fu, X.; Lei, Z.; Wang, K.; Yan, J. 2015. Low cost carrier competition and route entry in an emerging but regulated aviation market - the case of China, Transportation Research Part A 79: 3-16. https://doi.org/10.1016/j.tra.2015.03.020

Gillen, D.; Morrison, W. G. 2005. Regulation, competition and network evolution in aviation, Journal of Air Transport Management 11(3): 161-174. https://doi.org/10.1016/j.jairtraman.2005.03.002

Harford, J. 2005. What drives merger waves?, Journal of Financial Economics 77(3): 529-560. https://doi.org/10.1016/j.jineco.2004.05.004

Honert, R. C. V. D.; Stewart, T. J. 1992. A game-theoretic model for mergers and acquisitions, European Journal of Operational Research 59(2): 275-287. https://doi.org/10.1016/0377-2217(92)90141-U 
Kole, S. R.; Lehn, K. M. 1999. Deregulation and the adaptation of governance structure: the case of the U.S. airline industry, Journal of Financial Economics 52(1): 79-117. https://doi.org/10.1016/S0304-405X(99)00005-7

Kumar, S.; Bansal, L. K. 2008. The impact of mergers and acquisitions on corporate performance in India, Management Decision 46(10): 1531-1543. https://doi.org/10.1108/00251740810920029

Lei, Z.; O'Connell, J. F. 2011. The evolving landscape of Chinese aviation policies and impact of a deregulating environment on Chinese carriers, Journal of Transport Geography 19(4): 829-839. https://doi.org/10.1016/j.jtrangeo.2010.10.010

Lin, M. H. 2004. Strategic airline alliances and endogenous Stackelberg equilibria, Transportation Research Part E 40(5): 357-384. https://doi.org/10.1016/j.tre.2003.09.001

Lin, M. H. 2008. Airline alliances and entry deterrence, Transportation Research Part E 44(4): 637-652. https://doi.org/10.1016/j.tre.2007.05.003

Mar, P.; Young, M. N. 2001. Corporate governance in transition economies: a case study of two Chinese airlines, Journal of World Business 36(3): 280-302. https://doi.org/10.1016/S1090-9516(01)00056-6

Miles, S. J.; Mangold, W. G. 2005. Positioning Southwest Airlines through employee branding, Business Horizons 48: 535-545. https://doi.org/10.1016/j.bushor.2005.04.010

Park, K. H. 2009. Has bank consolidation in Korea lessened competition?, The Quarterly Review of Economics and Finance 49(2): 651-667. https://doi.org/10.1016/j.qref.2008.02.003

Peng, M. 2010. Global business. $2^{\text {nd }}$ ed. Cengage Learning.

Powers, I. Y. 1987. A game-theoretic model of corporate takeovers by major stockholders, Management Science 33(4): 467-483. https://doi.org/10.1287/mnsc.33.4.467

Shaw, S. L.; Lu, F.; Chen, J.; Zhou, C. 2009. China's airline consolidation and its effects on domestic airline networks and competition, Journal of Transport Geography 17(4): 293-305. https://doi.org/10.1016/j.jtrangeo.2009.02.005

Tahmincioglu, E. 2006. Double vision, Workforce Management 85(1): 22-28.

The World Bank. 2016. Air Transport, passengers carried [online], [cited 5 March 2016]. Available from Internet: http://data.worldbank.org/indicator/IS.AIR.PSGR

Tichy, G. 2001. What do we know about success and failure of mergers?, Journal of Industry, Competition and Trade 1(4): 347-394. https://doi.org/10.1023/A:1019521325295

Wang, K.; Fan, X.; Fu, X.; Zhou, Y. 2014. Benchmarking the performance of Chinese airlines: an investigation of productivity, yield and cost competitiveness, Journal of Air Transport Management 38: 3-14. https://doi.org/10.1016/j.jairtraman.2013.12.012

Zhang, Q.; Yang, H.; Wang, Q.; Zhang, A. 2014. Market power and its determinants in the Chinese airline industry, Transportation Research Part A: Policy and Practice 64(June): 1-13. https://doi.org/10.1016/j.tra.2014.03.003

Zhang, Y.; Round, D. K. 2008. China's airline deregulation since 1997 and the driving forces behind the 2002 airline consolidations, Journal of Air Transport Management 14(3): 130-142. https://doi.org/10.1016/j.jairtraman.2008.03.001

Zhang, Y.; Round, D. K. 2009. The effects of China's airline mergers on prices, Journal of Air Transport Management 15(6): 315-323. https://doi.org/10.1016/j.jairtraman.2009.04.005

Zhang, Y.; Round, D. K. 2011. Price wars and price collusion in China's airline markets, International Journal of Industrial Organization 29(4): 361-372. https://doi.org/10.1016/j.ijindorg.2010.07.005 


\section{APPENDIX}

\section{Supplementary note}

The analysis below is to provide proof of justification for focusing on the China aviation industry. An analysis is made between China and United States in terms of the total number of air passengers carried with data taken from the Worldbank. The trend for the Chinese aviation industry is exponentially increasing, which outpaces the United States. If the growth rates of both countries remain in its trajectory path, it is highly likely that China's aviation industry may dominate the United States.

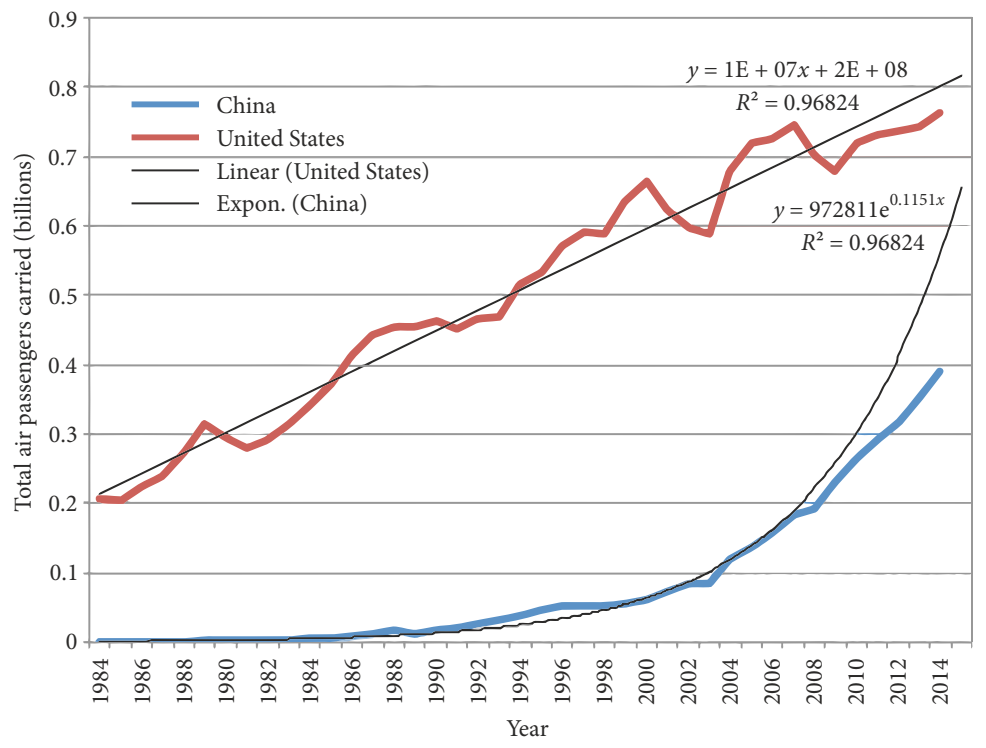

Data source: The World bank (2016) 